\title{
NIH backers take Clinton to task over impact of budget pact
}

[WASHINGTON] The potential ramifications for biomedical research of the balanced budget agreement recently struck by President Bill Clinton and congressional leaders have prompted a groundswell of concern from supporters of the US National Institutes of Health (NIH).

In a document prepared at the end of last month, the Office of Management and Budget $(\mathrm{OMB})$ estimates that, under the terms of the budget agreement, the NIH would be held to a 1.2 per cent increase in 1998 over its 1997 funding. That would be needed to allow funding for other, non-biomedical, spending explicitly protected in the budget deal.

Such an increase is far below the projected 3.1 per cent rate of biomedical inflation calculated by the NIH, based on the historical relationship between the general rate of inflation and inflation for biomedical goods and services. It also represents less than half of the 2.6 per cent increase contained in Clinton's formal budget request for 1998, released in February.

At the heart of the resulting criticism of these figures is the fact that, while Clinton has publicly and frequently applauded biomedical research, he did not make it one of the explicitly "protected areas" of domestic spending in the agreement he struck with Republican leaders of Congress last month.

This agreement would eliminate the US budget deficit by 2002, while protecting five areas of domestic spending. These include education and the environment and, within these, specific programmes covering subjects from national parks to immigrant education.

But the result is that the rest of the limited funds for domestic spending is tightly constrained - including that for NIH. "Clearly biomedical research was not treated as a priority and is very exposed because so many other things were treated as priorities by the president," said one biomedical lobbyist.

The OMB document estimates that, under the budget agreement, the NIH budget would need to be held to less than $\$ 12.9$ billion, rather than growing from $\$ 12.7$ billion in 1997 to $\$ 13.1$ billion in 1998 as Clinton requested in February.

Shortly after this estimate was sent to Congress, OMB officials distanced themselves from the figure, calling it a "mechanical" calculation. "It was not reviewed by any administration policy officials, and it should not be construed in any way to reflect the administration's position," Barry Anderson, OMB's assistant director for budget, wrote to the House of Representatives Appropriations Committee.
But the critics soon struck. John Porter (Republican, Illinois), chairman of the House appropriations subcommittee that oversees the NIH, last week called Clinton "contemptible" for publicly lauding the NIH and the importance of biomedical research without providing the dollars to pursue it. "The president has been great with the rhetoric, but he's been nowhere with the resources," Porter said.

Arlen Specter (Republican, Pennsylvania), Porter's Senate counterpart, took the director of NIH, Harold Varmus, to task at a hearing on 11 June. Varmus said that the administration had "assured" him that Clinton's February request for a 2.6 per cent (\$337 million) NIH increase still stood.

Specter called it an "illusion" that such an increase could be provided under the terms of the budget agreement, which would decrease by $\$ 100$ million the fund from which $\mathrm{NIH}$ and other health money is drawn. He called on Varmus and the other NIH direc- tors to get to grips with these "hard facts".

But Lawrence Haas, an OMB spokesman, said last Saturday (14 June) that there is enough money in the budget agreement "not only in 1998 but over the next five years to fully protect the president's priorities, of which NIH has always been one".

Last Friday, Porter's subcommittee learned that the money available for its 1998 spending bill has increased by $\$ 4.4$ billion over 1997. Porter is an ardent advocate of biomedical research and could normally be expected to use part of this increase to boost the NIH budget substantially. In the 1997 spending bill, he increased NIH's funding by 6.9 per cent.

But the unusual circumstances of this year's budget agreement mean that Porter may find himself less able to direct new money to the biomedical research agency. The agreement protects, for instance, education - an area that is also part of the Porter subcommittee's purview. Meredith Wadman

\section{Statistician is named to UK science post}

[LONDON] The British government is announcing this week that Anne Campbell, the Member of Parliament for Cambridge, has been appointed to a post in the Department of Trade and Industry, where her responsibilities are to include various science-related issues.

John Battle, the minister for industry, energy and science, is said to have told department officials last week that Campbell was to be appointed as his parliamentary private secretary, a relatively junior post in the ministerial pecking order, but one that still holds the potential for wielding considerable influence.

Campbell's appointment is likely to be widely welcomed in the scientific community. She is a former chair of the Parliamentary and Scientific Committee, which brings together politicians with industrial and academic scientists. As an active member of the House of Commons Select Committee on Science and Technology, she has been a vocal critic of weaknesses in the previous government's science policy.

Shortly before the general election, Campbell said that she would like to see the position of the chief scientific adviser to the government strengthened to ensure that "the government's overall strategy for science is better followed" (see Nature 386, $315 ; 1997)$. She has also attacked the way in which the latest 'prior options' review of government-funded research laboratories was carried out.

Her appointment is expected to help assuage widespread concern in the scientific

Campbell: keen to see bolder strategy. community that, although Battle is formally identified as the 'minister for science' - a capacity in which he has already attended several meetings of European research ministers - his portfolio is too broad to allow him to give research a substantial amount of his time.

Campbell, who has been an MP since 1992 , is a mathematician by training and a former college lecturer in statistics. In recent years, she has spoken out strongly in favour of increasing links between universities and industry, as well as calling for more government support for small, high-technology companies. She was also instrumental in helping to launch the group Scientists for Labour.

Campbell had been tipped by some as a possible science minister. But some feel that her prospects were tarnished when she declined to vote for Tony Blair in the Labour leadership election three years ago over the way that the vote was handled. David Dickson 